Pesq. Vet. Bras. 35(9):775-780, setembro 2015 DOI: 10.1590/S0100-736X2015000900002

\title{
Detection of virulence factors and antimicrobial resistance patterns in shiga toxin-producing Escherichia coli isolates from sheep ${ }^{1}$
}

\author{
Marcos R.A. Ferreira², Talícia dos S. Silva ${ }^{3}$, Ariel E. Stella4, Fabricio R. Conceição², \\ Edésio F. dos Reis ${ }^{5}$ and Cecília N. Moreira ${ }^{4 *}$
}

\begin{abstract}
Ferreira M.R.A., Silva T.S., Stella A.E., Conceição F.R., Reis E.F. \& Moreira C.N. 2015. Detection of virulence factors and antimicrobial resistance patterns in Shiga toxin-producing Escherichia coli isolates from sheep. Pesquisa Veterinária Brasileira 35(9):775-780. Departamento de Medicina Veterinária, Universidade Federal de Goiás, Regional Jataí, Rodovia BR-364 Km 192 no3.800, Parque Industrial, Cx. Postal 3, Jataí GO 75801-615, Brazil. E-mail: cissanm@yahoo.com.br

In order to detect virulence factors in Shiga toxin-producing Escherichia coli (STEC) isolates and investigate the antimicrobial resistance profile, rectal swabs were collected from healthy sheep of the races Santa Inês and Dorper. Of the 115 E. coli isolates obtained, $78.3 \%(90 / 115)$ were characterized as STEC, of which 52.2\% (47/90) carried stx1 gene, 33.3\% (30/90) stx2 and $14.5 \%$ (13/90) both genes. In search of virulence factors, $47.7 \%$ and $32.2 \%$ of the isolates carried the genes saa and cnf1. According to the analysis of the antimicrobial resistance profile, $83.3 \%$ (75/90) were resistant to at least one of the antibiotics tested. In phylogenetic classification grouped $24.4 \%$ (22/90) in group D (pathogenic), 32.2\% (29/90) in group B1 (commensal) and 43.3\% (39/90) in group A (commensal). The presence of several virulence factors as well as the high number of multiresistant isolates found in this study support the statement that sheep are potential carriers of pathogens threatening public health.
\end{abstract}

INDEX TERMS: Escherichia coli, STEC, multiresistant isolates, molecular characterization, phylogenetic.

RESUMO.- [Detecção de fatores de virulência e de resistência antimicrobiana em isolados produtores de toxina Shiga de ovinos.] A fim de detectar os fatores de virulência em isolados de E. coli produtoras de toxina Shiga (STEC) e investigar o perfil de resistência aos antimicrobianos, swabs retais foram coletados em ovelhas saudáveis das

\footnotetext{
${ }^{1}$ Received on March 6, 2015

Accepted for publication on June 26, 2015.

${ }^{2}$ Centro de Desenvolvimento Tecnológico, Biotecnologia, Universidade Federal de Pelotas, Campus Universitário s/n, Prédio 19, Cx. Postal 354, Pelotas RS 96010-900, Brazil. E-mails: marcosferreiravet@gmail.com, fabricio.rochedo@ufpel.edu.br

${ }^{3}$ Curso de Biomedicina, Universidade Federal de Goiás, Regional Jataí, Rodovia BR-364 Km 192, Setor Parque Industrial no 3.800, Cx. Postal 3, Jataí GO 75801-615. Brazil. E-mail: taliciabiomed@hotmail.com

${ }^{4}$ Curso de Medicina Veterinária, Universidade Federal de Goiás, Regional Jataí, Rodovia BR-364 Km 192, Setor Parque Industrial no 3.800, Cx. Postal 3. Jataí GO 75801-615. E-mail: ariel.vet@gmail.com; *Corresponding author: cissanm@yahoo.com.br

${ }^{5}$ Curso de Ciências Biológicas, Universidade Federal de Goiás, Regional Jataí, Rodovia BR-364 Km 192, Setor Parque Industrial no 3.800. Cx. Postal 3, Jataí G0 75801-615. E-mail: edesio7@brturbo.com.br
}

raças Santa Inês e Dorper. Dos 115 isolados de E. coli obtidos, 78,3\% (90/115) foram caracterizados como STEC, dos quais $52,2 \%$ (47/90) possuíam o gene stx $1,33,3 \%$ (30/90) stx2 e 14,5\% (13/90) ambos os genes. Em busca de fatores de virulência, $47,7 \%$ e $32,2 \%$ dos isolados apresentaram genes saa e cnf1. De acordo com a análise do perfil de resistência a antimicrobianos, 83,3\% (75/90) eram resistentes a pelo menos um dos antibióticos testados. Na classificação filogenética, os isolados foram agrupados 24,4\% (22/90) no grupo D (patogênico), 32,2\% (29/90) no grupo B1 (comensal) e 43,3\% (39/90) no grupo A (comensal). A presença de vários fatores de virulência, bem como o elevado número de isolados multirresistentes encontrados neste estudo apoia a afirmação de que as ovelhas são portadoras potenciais de patógenos que ameaçam a saúde pública.

TERMOS DE INDEXAÇÃO: Escherichia coli, STEC, isolados multirresistentes, caracterização molecular, filogenético.

\section{INTRODUCTION}

Shiga toxin-producing Escherichia coli (STEC) microorganisms cause severe human diseases, e.g., hemorrhagic co- 
litis (HC) and hemolytic uremic syndrome (HUS) (Nataro \& Kaper 1998). The HUS-causing STEC isolates are called enterohemorrhagic E. coli (EHEC) (Mainil 1999). They colonize the gastrointestinal tract of cattle and adult sheep without causing illness, but can induce serious diarrheagenic diseases in animals after weaning (Gyles et al. 2010, Ferens \& Hovde 2011, Kumar et al. 2012). The high prevalence of STEC isolates in these young animals represents a threat to public health for being highly pathogenic for humans (Gyles et al. 2010).

Healthy cattle are the main STEC reservoir, although some studies suggest that sheep also contribute significantly to the spread of these pathogens and consequently to the risk of human infection (Ferens \& Hovde 2011). The EHEC serotype 0157:H7 is the most relevant for humans and has been isolated worldwide from animal (meat and dairy) products and from feces of healthy sheep (Kumar et al. 2012, Momtaz et al. 2012).

Shiga toxins (stx) 1 and 2, encoded by the genes stx 1 and stx2, respectively, correspond to the major virulence factor of STEC and are responsible for blocking protein synthesis in eukaryotic cells (Gyles et al. 2010). The stx1 toxins have an amino acid sequence that is similar to that of the cytotoxin produced by Shigella dysenteriae serotype 1, though antigenically different (Beutin et al. 1997, Djordjevic et al. 2001). Epidemiological data indicate that stx2 is more often associated with severe diseases and HUS development than stx1 (Orth et al. 2007, Kawano et al. 2008). Although the production of stx 1 and/or stx2 and variants represents the main virulence factor of STEC, the ability of adhesion to the intestinal epithelium is the primary pathogenicity factor. The eae gene, which encodes intimin, is a $94-\mathrm{kDa}$ membrane protein involved in intestinal cell adhesion that triggers attaching and effacing injury (AE) (Jerse et al. 1990, McDaniel et al. 1995). Another important adhesin in STEC that do not encode the locus of enterocyte effacement (LEE-negative) is the STEC autoagglutinating adhesin (SAA) responsible for the adhesion and colonization of the bovine and ovine intestinal epithelium (Jenkins et al. 2003, Zweifel et al. 2005, Kumar et al. 2012).

Cytotoxic-necrotizing factors (CNFs) can be separated in two types of cytotoxins, CNF1 and CNF2 (Blanco et al. 1992). These cytotoxic-necrotizing factors are responsible for diarrheagenic diseases and other clinical signs in young lambs, but data in the literature on the distribution in healthy sheep and human are rather limited. CNF1-positive isolates (NTEC) have been widely reported in extra-intestinal infections (urinary tract infections - UTIs) (Dozois et al. 1997).

The indiscriminate use of antimicrobials in animal production paves the way for the development of resistance in microorganisms, both in commensal and potentially zoonotic pathogenic isolates (Zhang et al. 2009). In the last few years, the number of pathogenic isolates with antimicrobial multiresistance has increased, which narrows the options of antibiotics to treat human infections (Saei et al. 2012).

By evolutionary phenomena, several differentiated bacterial groups have emerged within microbial species. The classification of isolates based on the distribution analysis of pathogenicity markers in phylogenetic groups allowed the understanding of how pathogenic isolates acquired virulence genes (Johnson et al. 2001). In a pioneering study, Clermont et al. (2000) used the amplification of the genes chuA, yjaA and TspE4.C2 to classify E. coli isolates in four major phylogenetic groups (A, B1, B2 and D).

Currently, a sheep herd with a total of approximately 191,000 animals is maintained, primarily for meat production, in the state of Goiás, Brazil (IBGE 2014). In view of the importance of sheep in the State economy and also in view of the potential spread of public health-threatening pathogens, the aim of this study was to characterize the virulence factors of STEC isolates obtained from rectal swabs of healthy sheep in this State, evaluating the prevalence of 0157:H7 and non-0157:H7 isolates by molecular characterization, as well as determine the profile of antimicrobial resistance and phylogenetic distribution of these isolates.

\section{MATERIALS AND METHODS}

Sampling and Escherichia coli isolation. Rectal swabs of 23 healthy Santa Inês and Dorper sheep on a farm in the municipality of Jataí, GO, were collected, 17 of which were adult Santa Inês females, one an adult Dorper male, and five Santa Inês x Dorper crossbred lambs, of which three females and two males, totaling 18 adults and five young animals. The swabs were inoculated in Stuart medium tubes (Difco Laboratories, Detroit, MI, USA), ice-cooled, and analyzed within $24 \mathrm{~h}$. The fecal samples were streaked onto Levine BEM agar (Difco, Detroit, MI, USA) and incubated at $37^{\circ} \mathrm{C}$ for $24 \mathrm{~h}$. At least five suspect individual E. coli colonies (dark with a greenish metallic sheen) per animal were chosen, and their identity was confirmed by biochemical tests, using citrate and the production of indole, acetoin, and methyl red reactive compounds (Koneman et al. 2008).

Molecular characterization. DNA samples were extracted from the isolates $(n=115)$ according to (Keskimäki et al. 2001). Initially, these samples were analyzed by PCR for the presence of $16 S r R N A$ (internal control), stx 1 and st 2 , for STEC characterization. DNA samples from 90 STEC positive isolates were analyzed by PCR for the presence of the $r f b 0157$ and fliCh7 genes, for identification of 0157:H7 isolates. DNA from the STEC positive isolates was analyzed by PCR for the presence of the eae, ehxA, saa and cnf1 virulence factor genes. The amplification protocol was carried out in a MJ Research thermocycler using the PCR test conditions and primers as described previously: stx 2 and rfb0157 (Paton \& Paton 1998), fliCh7 (Gannon et al. 1997), stx1 and eae (Wang et al. 2002), saa (Paton \& Paton 2002), ehxA (Blanco et al. 2004) and cnf1 (Yamamoto et al. 1995). The phylogenetic classification of STEC was performed by PCR as described by Clermont et al. (2000) using the chuA, yjaA and TSPE4.C2 genes. The 232/96 isolate, kindly provided by the Laboratory of Bacteriology in Department of Preventive Veterinary Medicine at the Federal University of Santa Maria, was used as positive control. The primers sequences for molecular characterization of virulence factors of isolates, as well as primers for determination of phylogenetic groups are presented in Table 1. E. coli 0157:H7 (ATCC EDL 933) and Klebsiella pneumoniae (ATCC BAA 1705) DNA were used as positive and negative controls, respectively. 
Table 1. Oligonucleotides used in this study

\begin{tabular}{|c|c|c|c|c|}
\hline $\begin{array}{l}\text { Target } \\
\text { gene }\end{array}$ & Primer Sequence & $\begin{array}{c}\text { Amplicon } \\
\text { (bp) }\end{array}$ & $\begin{array}{c}\text { Location } \\
\text { within gene }\end{array}$ & $\begin{array}{l}\text { GenBank } \\
\text { accession }\end{array}$ \\
\hline \multirow[t]{2}{*}{$16 S r R N A$} & CCCCCTGGACGAAGACTGAC & 401 & $1682-1701$ & AB035924 \\
\hline & ACCGCTGGCAACAAAGGATA & & $2063-2082$ & \\
\hline \multirow[t]{2}{*}{ stx1 } & TCTCAGTGGGCGTTCTTATG & 338 & 777-796 & M17358 \\
\hline & TACССССТСААСТGСТАAТА & & $1095-1114$ & \\
\hline \multirow[t]{2}{*}{ stx2 } & GGCACTGTCTGAAACTGCTCC & 255 & $603-623$ & NC_004914 \\
\hline & TCGCCAGTTATCTGACATTCTG & & 837-857 & \\
\hline \multirow[t]{2}{*}{ eae } & ATGCTTAGTGCTGGTTTAGG & 248 & 132-151 & Z11541.1 \\
\hline & GCCTTCATCATTTCGCTTTC & & $360-379$ & \\
\hline \multirow{2}{*}{ rfb0157 } & CGGACATCCATGTGATATGG & 259 & $393-412$ & JF713072.1 \\
\hline & TTGCCTATGTACAGCTAATCC & & $631-651$ & \\
\hline \multirow[t]{2}{*}{ chuA } & GACGAACCAACGGTCAGGAT & 279 & $245-264$ & AF280396.1 \\
\hline & TGCCGCCAGTACCAAAGACA & & 504-523 & \\
\hline \multirow[t]{2}{*}{ yjaA } & TGAAGTGTCAGGAGACGCTG & 211 & $66-84$ & NC_007779.1 \\
\hline & ATGGAGAATGCGTTCCTCAAC & & $257-276$ & \\
\hline \multirow[t]{2}{*}{ TSPE4.C2 } & GAGTAATGTCGGGGCATTCA & 152 & $421-440$ & AE014075.1 \\
\hline & CGCGCCAACAAAGTATTACG & & $553-572$ & \\
\hline \multirow[t]{2}{*}{ fliCh7 } & GCGCTGTCGAGTTCTATCGAGC & 625 & 69-91 & AB781292.1 \\
\hline & CAACGGTGACTTTATCGCCATTCC & & $671-694$ & \\
\hline \multirow[t]{2}{*}{ cnf1 } & AAGATGGAGTTTCCTATGCAGGAG & 498 & 794-817 & NC_00796.1 \\
\hline & CATTCAGAGTCCTGCCCTCATTATT & & $1267-1291$ & \\
\hline \multirow[t]{2}{*}{$e h x A$} & GGTGCAGCAGAAAAAGTTGTAG & 1551 & $238-259$ & ES204929.1 \\
\hline & TCTCGCCTGATAGTGTTTGGTA & & 1767-1788 & \\
\hline \multirow[t]{2}{*}{ saa } & CGTGATGAACAGGCTATTGC & 119 & $1477-1496$ & NC_007365.1 \\
\hline & ATGGACATGCCTGTGGCAAC & & $1576-1595$ & \\
\hline
\end{tabular}

The amplified products were viewed after molecular mass determination by $1 \%$ agarose gel electrophoresis at $70 \mathrm{~V}$ for 120 min, in $1 \times$ TBE buffer (Tris- $\mathrm{HCl}$ of $89 \mathrm{mM}$, boric acid of $89 \mathrm{mM}$, EDTA of $2.5 \mathrm{mM}, \mathrm{pH} 8.0)$. A DNA ladder ( $\varphi \mathrm{X} 174 /$ HaeIII) was used as molecular mass pattern; the gels were stained with ethidium bromide $(0.5 \mu \mathrm{g} / \mathrm{mL})$.

Antimicrobial resistance patterns. For the determination of the antimicrobial resistance profile, the isolates were subcultured in BHI broth for 18 hours at $37^{\circ} \mathrm{C}$, until turbidity reached 0.5 on the McFarland scale. After growth, isolates were plated on Mueller-Hinton agar (disk diffusion method), using the following antibiotics: $30 \mu \mathrm{g}$ ceftiofur (CTF), $30 \mu \mathrm{g}$ amikacin (AMI), $10 \mu \mathrm{g}$ gentamicin (GEN), $30 \mu \mathrm{g}$ tetracycline (TET), $30 \mu \mathrm{g}$ chloramphenicol (CLO), 23.75/1.25 $\mu \mathrm{g}$ sulfametoxazol + trimethoprim (SXT), $30 \mu \mathrm{g}$ ceftazidin (CAZ), $30+30 \mu \mathrm{g}$ amoxicillin + clavulanic acid (AMC), $10 \mu \mathrm{g}$ nalidixic acid (NAL), $10 \mu \mathrm{g}$ streptomycin (EST), and $30 \mu \mathrm{g}$ cefoxitin (CFO). After 18 hours of incubation at $37^{\circ} \mathrm{C}$, the inhibition halo in each test was measured and the s classified as resistant, sensitive or intermediate, according to the (Clinical Laboratory Standards Institute 2008).

Ethical aspects. The study activities were carried out and the animals treated according to the international standards and in compliance with the ethical principles of animal experimentation established by COBEA (Colégio Brasileiro de Experimentação Animal) (protocol 206/2009/CEUA/UFG).

\section{RESULTS}

From the 115 Escherichia coli sheep isolates, 78.3\% $(90 / 115)$ were characterized as STEC, of which $52.2 \%$ (47/90) contained stx1 gene, 33.3\% (30/90) stx2 and $14.5 \%(13 / 90)$ both stx1/stx2 genes. In terms of the distribution of STEC isolates per animal category, 60\% (15/25) isolated from lambs, $82.2 \%$ (70/85) from adult females and $100 \%(5 / 5)$ from adult males. Distribution of the virulence genes according to the profile Shiga toxin of the isolates STEC are discriminates in Table 2. In current work, were not detected STEC/0157:H7-positives (genes
Table 2. Virulence genes according to the profile Shiga toxin of the isolates STEC

\begin{tabular}{cccc}
\hline Virulence & \multicolumn{3}{c}{ Shiga Toxin } \\
\cline { 2 - 4 } genes $(\%)$ & stx1 & stx2 & stx1/stx2 \\
\hline saa & $72.1(31 / 43)$ & $18.6(8 / 43)$ & $9.3(6 / 43)$ \\
cnf1 & $69(20 / 29)$ & $24.1(7 / 29)$ & $6.9(2 / 29)$
\end{tabular}

Table 3. Patterns of antimicrobial resistance and virulence factors in STEC

\begin{tabular}{lcccc}
\hline Antibiotics & \multicolumn{3}{c}{ Shiga Toxin } & $\begin{array}{c}\text { Resistance } \\
\text { profile (\%) }\end{array}$ \\
\cline { 2 - 4 } & stx1 & stx2 & stx1/stx2 & $20(18 / 90)$ \\
AMC 30 $^{\mathrm{a}}$ & 9 & 5 & 4 & $1.1(1 / 90)$ \\
$\mathrm{CTF}^{\mathrm{b}}$ & 1 & - & - & $1.1(1 / 90)$ \\
$\mathrm{AMI}^{\mathrm{c}}$ & - & - & 1 & $1.1(1 / 90)$ \\
$\mathrm{CFO}^{\mathrm{d}}$ & - & - & 1 & $4.5(4 / 90)$ \\
$\mathrm{GEN}^{\mathrm{e}}$ & 1 & 3 & - & $20(18 / 90)$ \\
NAL $^{\mathrm{f}}$ & 8 & 6 & 4 & $28.8(26 / 90)$ \\
EST $^{\mathrm{g}}$ & 16 & 7 & 3 & $12.2(11 / 90)$ \\
TET $^{\mathrm{h}}$ & 5 & 5 & 1 & $4.5(4 / 90)$ \\
$\mathrm{CLO}^{\mathrm{i}}$ & 1 & 3 & - & $1.1(1 / 90)$ \\
SXT $^{\mathrm{j}}$ & 1 & - & - & $5.6(5 / 90)$ \\
CAZ $^{1}$ & 1 & - & 4 &
\end{tabular}

${ }^{a}$ Amoxicillin + Clavulanic Acid, ${ }^{\mathrm{b}}$ Ceftiofur, ${ }^{\mathrm{c}}$ Amikacin, ${ }^{\mathrm{d}}$ Cefoxitin, ${ }^{\mathrm{e}}$ Gentamicin, ${ }^{\mathrm{f}}$ Nalidixic acid, ${ }^{\mathrm{g}}$ Streptomycin, ${ }^{\mathrm{h}}$ Tetracycline, ${ }^{\mathrm{i}}$ Chloramphenicol, ${ }^{\mathrm{j}}$ Sulfamethoxazole ${ }^{+}$Trimethoprim, ${ }^{1}$ Ceftazidin.

rfb0157 and fliCh7), as well as were negatives for $e h x A$ and eae genes.

The analysis of the antimicrobial resistance profile showed that $83.3 \%$ (75/90) STEC from sheep feces were resistant to at least one antibiotic (mainly to streptomycin, nalidixic acid and amoxicillin 30), 12.2\% (11/90) of STEC were resistant to two antibiotics (nalidixic acid + ampicillin 30; nalidixic acid + streptomycin) and 6.7\% (6/90) were resistant to more than three antibiotics, mainly to gentamicin, streptomycin and tetracycline. The distributions of the 
Table 4. Distribution of STEC isolates with regard to the presence of virulence genes according to the phylogenetic group to which they belong

\begin{tabular}{cccc}
\hline \multirow{2}{*}{ Phylogenetic group } & \multicolumn{3}{c}{ Virulence gene (\%) } \\
\cline { 2 - 4 } & stx1 & stx2 & stx1/stx2 \\
\hline A (n=39) & $46.2(17 / 39)$ & $30.8(12 / 39)$ & $23(10 / 39)$ \\
B1 (n=29) & $79.3(23 / 29)$ & $17.2(4 / 29)$ & $3.5(2 / 29)$ \\
Commensal A+B1 (n=68) & $58.8(40 / 68)$ & $23.5(16 / 68)$ & $17.7(12 / 68)$ \\
D (n=22) & $31.8(7 / 22)$ & $63.6(14 / 22)$ & $4.5(1 / 22)$ \\
B2 (n=0)0 (0) & $0(0)$ & $0(0)$ & \\
Pathogenic D+B2 (n=22) & $31.8(7 / 22)$ & $63.6(14 / 22)$ & $4.5(1 / 22)$ \\
Total (n=90) & $52.2(47 / 90)$ & $33.3(30 / 90)$ & $14.5(13 / 90)$
\end{tabular}

antibiotic resistance profile according to stx production are listed in Table 3.

The phylogenetic classification grouped $24.4 \%$ (22/90) in group D (pathogenic), 32.2\% (29/90) in group B1 (commensal) and $43.3 \%(39 / 90)$ in group A (commensal). The distribution of STEC isolates with regard to the presence of stx 1 and stx 2 genes according to the phylogenetic group to which they belong is shown in Table 4 .

\section{DISCUSSION}

Ruminants, in particular healthy cattle and sheep, are the main reservoirs of STEC, by passing the fecal route and acting as a source of contamination of animal products, thus representing a potential pathogenic threat to human health (Martin \& Beutin 2011). Studies by Ferreira et al. (2014) and Freitas-Filho et al. (2014) were pioneering in determining the prevalence of STEC and STEC/0157:H7 in healthy cattle in the State of Goiás, Brazil, while our study evaluated the virulence factors and antimicrobial resistance in STEC isolates obtained from healthy sheep in this State. On the contrary, Blanco et al. (2003) found a higher prevalence of non-0157 STEC in sheep compared to cattle, where our study did not reveal the difference between sheep (78.3\%) and cattle $(72.7 \%)$ (Ferreira et al. 2014). However, it would be appropriate evaluation larger number of sheep to determine such difference between those species.

In this study, the prevalence of stx 1 and stx 2 gene in STEC isolates was higher 52.2\% (47/90) and 33.3\% (30/90) respectively, as similarly found by Ghanbarpour \& Kiani (2013) and Blanco et al. (2003) in their studies, where $46.5 \%$ (20/43) and 55\% (213/384) of the STEC isolates carried stx1. On the other hand, Oporto et al. (2008) observed a prevalence of $67.4 \%$ of stx $1 /$ st $x 2$, far above the $17.9 \%$ of stx 1 in STEC isolated from sheep in Spain. Experiments with rats indicated that stx2 is 100 times more potent than stx1 (Tesh et al. 1993). In a work carried out in primates, the intravenous inoculation of stx 2 produces HUS symptoms, while administration of the same dose of stx1 did not induce the syndrome (Stearns-Kurosawa et al. 2010). Although stx 2 is more toxic to humans, stx 1 has also been attributed in severe illness such as HUS (Hedican et al. 2009).

In the evaluation of the prevalence of STEC/0157:H7 by multiplex PCR, the results were negative for genes $r f b 0157$ and flicH 7 in the isolates. Similar results were observed by (Pinaka et al. 2013), who detected no rfbO157 and flicH7 genes in isolates from goats, sheep and cattle, but found eae in $54.9 \%$ (28/51), which was not confirmed in our study. Also in Spain, the majority of sheep STEC isolates was non-0157, with only 8.7\% 0157:H7-positive STEC (Oporto et al. 2008). 0157 STEC isolates are worldwide involved in different disease outbreaks in humans, while in recent years, outbreaks involving non-0157 isolates have been increasingly reported (Hedican et al. 2009, Scheutz et al. 2011).

In search of genes for other virulence factors, $32.2 \%$ of the isolates carried gene $\mathrm{cnf1}$, and none of the isolates eae and $e h x A$. Sheep can act as main disseminators of this pathogen in animal-derived food products and water and as direct transmitters to humans, however, studies on the distribution of CNF-1 in STEC isolates from healthy sheep are limited. In this study we found the presence of $c n f 1$ gene in $32.2 \%(29 / 90)$ of STEC isolates from healthy sheep, which is higher than reported in previous studies (Orden et al. 2007, Aragão et al. 2012). The STEC isolates carrying the cnf1 gene were widely reported in relation to HUS outbreaks in humans (Dozois et al. 1997), and our study confirmed the importance of this virulence factor of STEC isolates from sheep in the state of Goiás as a potential threat to human health.

Paton \& Paton (1998) first described the SAA in non-0157 STEC serotypes. Subsequently, several authors reported the presence of the saa gene in bovine and ovine STEC isolates, correlating the intestinal colonization in the host with the presence of this gene (Zweifel et al. 2005, Aidar-Ugrinovich et al. 2007). This study was the first to determine the presence of the saa gene in ovine STEC in the state of Goiás, reporting a prevalence of $47.7 \%$ (43/90). The saa gene is potential pathogenic marker in eae-negatives STEC isolates, and its product can cause a systemic and gastrointestinal disease in humans (Rey et al. 2003). Jenkins et al. (2003) reported saa-positives STEC in 13\% $(6 / 46)$ of human patients with HUS and 7\% (2/29) of STEC isolates of patients with diarrhea or bloody diarrhea.

The resistance profile showed that $83.3 \%$ (75/90) of the antimicrobials were resistant to at least one of the antibiotics tested. The results indicate greater resistance to streptomycin $(25.5 \%)$, amoxicillin + clavulanic acid $(22.2 \%)$, and nalidixic acid (18.9\%). Antibiotics with greatest sensitivity were ceftriaxone (100\%), amikacin (98\%), cefoxitin (98\%), sulfametazol + trimethoprim (98\%), and cefotaxime (98\%). Ghanbarpour \& Kiani (2013) found 192 ovine STEC isolates to be resistant to at least one of eight tested antibiotics, the antibiotics to which resistance was highest were penicillin (98.4\%), cephalexin (94.8\%) and tetracycline (91.2\%), resistance was lowest to sulfamethoxazole + trimethoprim (51\%) and ciprofloxacin (62\%), and $28.6 \%$ isolates were resistant to all antibiotics tested.

Relating the virulence factors with resistance to the tested antibiotics, the stx1-positive STEC isolates were most resistant; $50.7 \%$ (38/75) isolates were resistant to at least one antibiotic, followed by $30.7 \%(23 / 75)$ stx2-positive STEC isolates and $18.7 \%(14 / 75)$ stx $1 /$ stx 2 isolates. In Spain, 0157:H7 STEC isolated from sheep, cattle and humans were detected, with a resistance profile of $20 \%(1 / 5)$ of ovine and 53\% (42/82) of cattle; in bovine STEC, Mora 
et al. (2004) observed greatest resistance to streptomycin (19\%), in agreement with our results. Also similarly to our study, Saei et al. (2012) reported low resistance to the antibiotics tetracycline $(10 \%)$ and gentamicin (4\%).

According to the phylogenetic classification, $24.4 \%$ $(22 / 90)$ were from group D (pathogenic), 32.2\% (29/90) from group B1 (commensal) and 43.3\% (39/90) from group A (commensal). Ghanbarpour \& Kiani (2013) also found three distinct phylogenetic groups: A (42.7\%), B1 $(48.4 \%)$ and D (8.8\%) of the 192 ovine STEC isolates, with no isolates of the phylogenetic group B2 either. The group B1 is considered prevalent among phylogenetic groups in STEC isolated in the feces of domestic ruminants (Carlos et al. 2010).

When relating the phylogenetic results with virulence factors, it was shown that the stx1-positive STEC were primarily of the pathogenic phylogenetic group $\mathrm{D}$, while the isolates stx2 and stx1/stx2 were mostly commensal (A or B1). However, regardless of the phylogenetic classification, the virulence factors of the isolates make them capable of causing disease. This can most likely be explained by the high ability to transfer genetic material between commensal and pathogenic Eschrichia coli (Hao et al. 2012).

STEC isolates are highly pathogenic for humans, mainly for being involved in diarrheagenic diseases, hemorrhagic colitis (HC) and hemolytic uremic syndrome (HUS) in humans. Several studies investigated the prevalence of STEC in ruminants, particularly in cattle and sheep, however studies for this purpose are scarce for certain regions of Brazil, as for the State of Goiás. The high number of STEC-positive isolates in sheep and the high pathogenicity, confirmed by the presence of virulence factors as well as the large number of multiresistants detected in this study, support the statement that small ruminants are potential carriers of these pathogens and a potential threat to public health.

Acknowledgements.- This study was supported by grant 503886/20092 from Conselho Nacional de Desenvolvimento Científico e Tecnológico (CNPq).

\section{REFERENCES}

Aidar-Ugrinovich L., Blanco J., Blanco M., Blanco J.E., Leomil L., Dahbi G., Mora A., Onuma D.L., Silveira W.D. \& Pestana de Castro A. 2007. Serotypes, virulence genes, and intimin types of Shiga toxin-producing Escherichia coli (STEC) and enteropathogenic E. coli (EPEC) isolated from calves in São Paulo, Brazil. Int. J. Food Microbiol. 115:297-306.

Aragão A.Z.B., Teocchi M.A., Fregolente M.C.D., Gatti S.V., Pires A.V. \& Yano T. 2012. Colibacillosis in lambs is associated to type I heat-stable enterotoxin in a farm in São Paulo State, Brazil. Ciência Rural 42:854-857.

Beutin L., Geier D., Zimmermann S., Aleksic S., Gillespie H. \& Whittam T.S. 1997. Epidemiological relatedness and clonal types of natural populations of Escherichia coli producing Shiga toxins in separate populations of cattle and sheep. Appl. Environ. Microb. 63:2175-2180.

Blanco J., Blanco M., Alonso M.P., Blanco J.E., Garabal J. \& Gonzalez E.A. 1992. Serogroups of Escherichia coli producing cytotoxic necrotizing factors CNF1 and CNF2. FEMS Microbiol. Lett. 96:155-159.

Blanco M., Blanco J.E., Mora A., Dahbi G., Alonso M.P., González E.A., Bernárdez M.I. \& Blanco J. 2004. Serotypes, virulence genes and intimin types of Shiga toxin (Verotoxin)-producing Escherichia coli isolates from cattle in spain and identification of a new intimin variant gene (eae- $\xi$ ). J. Clin. Microbiol. 42:645-651.

Blanco M., Blanco J.E., Mora A., Rey J., Alonso J.M., Hermoso M., Hermoso
J., Alonso M.P., Dahbi G., González E.A., Bernárdez M.I. \& Blanco J. 2003. Types of Shiga toxin (Verotoxin)-producing Escherichia coli isolates from healthy sheep in Spain serotypes, virulence genes, and intimin types of Shiga toxin (Verotoxin)-producing Escherichia coli isolates from healthy sheep in Spain. J. Clin. Microbiol. 41:1351-1356.

Carlos C., Pires M.M., Stoppe N.C., Hachich E.M., Sato M., Gomes T.A.T., Amaral L.A. \& Ottoboni L.M.M. 2010. Escherichia coli phylogenetic group determination and its application in the identification of the major animal source of fecal contamination. BMC Microbiol. 10:161:1-10.

Clermont O., Bonacorsi P. \& Bingen E. 2000. Rapid and simple determination of the Escherichia coli phylogenetic group. Appl. Environ. Microbiol. 66:4555-4558.

Clinical Laboratory Standards Institute (CLSI) 2008. Performance Standards for Antimicrobial Disk and Diluition Susceptibility Tests for Bacteria Isolated from Animals: approved standard. 3rd ed. Clinical and Laboratory Standards Institute, Wayne, Pennsylvania, 28(8):2-11.

Djordjevic S.P., Hornitzky M.A., Bailey G., Gill P., Vanselow B., Walker K., Karl A. \& Bettelheim K. 2001. Virulence properties and serotypes of Shiga toxin-producing Escherichia coli from healthy australian slaughter-age sheep virulence properties and serotypes of Shiga toxin-producing Escherichia coli from healthy Australian slaughter-age sheep. J. Clin. Microbiol. 39:2017-2021.

Dozois C.M., Clément S., Desautels C., Oswald E. \& Fairbrother J.M. 1997. Expression of $\mathrm{P}, \mathrm{S}$, and $\mathrm{F} 1 \mathrm{C}$ adhesins by cytotoxic necrotizing factor 1-producing Escherichia coli from septicemic and diarrheic pigs. FEMS Microbiol. Lett. 152:307-312.

Ferens W.A. \& Hovde C.J. 2011. Escherichia coli 0157:H7: animal reservoir and sources of human infection. Foodborne Pathog. Dis. 8:465-487.

Ferreira M.R.A., Filho-Freitas E.G., Pinto J.F.N., Dias M. \& Moreira C.N. 2014. Isolation, prevalence, and risk factors for infection by shiga toxin-producing Escherichia coli (STEC) in dairy cattle. Trop. Anim. Health Prod. 46:635-639.

Freitas-Filho E.G., Ferreira M.R.A., Pinto J.F.N., Conceição F.R. \& Moreira C.N. 2014. Enterohemorrhagic Escherichia coli 0157:H7 from healthy dairy cattle in Mid-West Brazil: occurrence and molecular characterization. Pesq. Vet. Bras. 34:24-28.

Gannon V.P., Souza S., Graham T., King R.K., Rahn K., Read S. \& Gannon V. 1997. Use of the flagellar H7 gene as a target in multiplex PCR assays and improved specificity in identification of enterohemorrhagic Escherichia coli. J. Clin. Microbiol. 35:656-662.

Ghanbarpour R. \& Kiani M. 2013. Characterization of non-0157 shiga toxin-producing Escherichia coli isolates from healthy fat-tailed sheep in southeastern of Iran. Trop. Anim. Health Prod. 45:641-648.

Gyles C.L., Prescott J.F., Songer J. \& Thoen C.O. 2010. Pathogenesis of Bacterial Infection in Animals, 4th ed., Wiley-Blackwell, Ames, Iowa, USA.

Hao W., Allen V.G., Jamieson F.B., Low D.E. \& Alexander D.C. 2012. Phylogenetic incongruence in E. coli 0104: understanding the evolutionary relationships of emerging pathogens in the face of homologous recombination. PloS One 7:e33971.

Hedican E.B., Medus C., Besser J.M., Juni B.A., Koziol B., Taylor C. \& Smith K.E. 2009. Characteristics of 0157 versus non-0157 Shiga toxin-producing Escherichia coli infections in Minnesota, 2000-2006. Clin. Infect. Dis. 49:358-364.

IBGE 2014. Instituto Brasileiro de Geografia e Estatística <http://www. ibge.gov.br/estadosat/temas.php?sigla=go\&tema=pecuaria2012> Accessed 24 May 2014.

Jenkins C., Perry N.T., Cheasty T., Shaw D.J., Frankel G., Dougan G., Gunn G.J., Smith H.R., Paton A.W. \& Paton J.C. 2003. Distribution of the saa gene in strains of Shiga toxin-producing Escherichia coli of human and bovine origins. J. Clin. Microbiol. 41:1775-1778.

Jerse A.E., Jun Y., Tall B.D. \& James J.B. 1990. A genetic locus of enteropathogenic Escherichia coli necessary for the production of attaching and effacing lesions on tissue culture cells. Proc. Natl Acad. Sci. USA 87:7839-7843.

Johnson J.R., Delavari P., Kuskowski M. \& Stell A.L. 2001. Phylogenetic distribution of extraintestinal virulence-associated traits in Escherichia coli. J. Infect. Dis. 183:78-88. 
Kawano K., Okada M., Haga T., Maeda K. \& Goto Y. 2008. Relationship between pathogenicity for humans and stx genotype in Shiga toxin-producing Escherichia coli serotype 0157. Eur. J. Clin. Microbiol. 27:227-232.

Keskimäki M., Eklund M., Pesonen H., Heiskanen T. \& Siitonen A. 2001. EPEC, EAEC and STEC in stool specimens: prevalence and molecular epidemiology of isolates. Diagn. Microbiol. Infect. Dis. 40:151-156.

Koneman E.W., Allen S.D., Janda W.M., Procop G., Schreckenberger P.C. \& Winn W.C. 2008. Diagnóstico Microbiológico: texto e atlas, colorido. $6^{\underline{a}}$ edição. Guanabara Koogan, Rio de Janeiro, Brazil. 1565p.

Kumar A., Taneja N., Kumar Y. \& Sharma M. 2012. Detection of Shiga toxin variants among Shiga toxin-forming Escherichia coli isolates from animal stool, meat and human stool samples in India. J. Appl. Microbiol. 113:1208-1216.

Mainil J. 1999. Shiga/verocytotoxins and Shiga/verotoxigenic Escherichia coli in animals. Vet. Res. 30:235-257.

Martin A. \& Beutin L. 2011. Characteristics of Shiga toxin-producing Escherichia coli from meat and milk products of different origins and association with food producing animals as main contamination sources. Int. J. Food. Microbiol. 146:99-104.

McDaniel T.K., Jarvis K.G., Donnenbergt M.S. \& James J.B. 1995. A genetic locus of enterocyte effacement conserved among diverse enterobacterial pathogens. Proc. Natl Acad. Sci. USA 92:1664-1668.

Momtaz H., Farzan R., Rahimi E., Safarpoor-Dehkordi F. \& Souod N. 2012. Molecular characterization of Shiga toxin-producing Escherichia coli isolated from ruminant and donkey raw milk samples and traditional dairy products in Iran. Scient. Scient. World J. 2012:1-13.

Mora A., Blanco M., Blanco J.E., Alonso M.P., Dhabi G., Thomson-Carter F., Usera M.A., Bartolomé R., Prats G. \& Blanco J. 2004. Phage types and genotypes of Shiga toxin-produxing E. coli 0157:H7 isolates from humans and animals in Spain: Identification and characterization of two predominating Phage types (PT2 and PT8). J. Biochem. 42:4007-4015.

Nataro J.P. \& Kaper J.B. 1998. Diarrheagenic Escherichia coli. Clin. Microbiol. Reviews 11:142-201.

Oporto B., Esteban J.I., Aduriz G., Juste R.A. \& Hurtado A. 2008. Escherichia coli 0157:H7 and non-0157 Shiga toxin-producing E. coli in healthy cattle, sheep and swine herds in Northern Spain. Zoonoses Public Health 55:73-81.

Orden J.A., Domínguez-Bernal G., Martínez-Pulgarín S., Blanco M., Blanco J.E., Mora A., Blanco J. \& Del la Fuente R. 2007. Necrotoxigenic Escherichia coli from sheep and goats produce a new type of cytotoxic necrotizing factor (CNF3) associated with the eae and ehxA genes. Int. Microbiol. 10:47-55.

Orth D., Grif K., Khan A.B., Naim A., Dierich M.P. \& Würzner R. 2007. The Shiga toxin genotype rather than the amount of Shiga toxin or the cytotoxicity of Shiga toxin in vitro correlates with the appearance of the hemolytic uremic syndrome. Diagn. Microbiol. Infect. Dis. 59:235-242.
Paton A.W. \& Paton J.C. 1998. Detection and characterization of Shiga toxigenic Escherichia coli by using multiplex PCR Assays for stx1, stx2, eae, enterohemorrhagic E. coli hlyA, rfb0111 and rfb0157. J. Clin. Microbiol. 36:598-602.

Paton A.W. \& Paton J.C. 2002. Direct detection and characterization of Shiga toxigenic Escherichia coli by multiplex PCR for stx1, stx2, eae, ehxA and saa. J. Clin. Microbiol. 40:271-274.

Pinaka O., Pournaras S., Mouchtouri V., Plakokefalos E., Katsiaflaka A., Kolokythopoulou F., Barboutsi E., Bitsolas N. \& Hadjichristodoulou C. 2013. Shiga toxin-producing Escherichia coli in Central Greece: prevalence and virulence genes of 0157:H7 and non-0157 in animal feces, vegetables, and humans. Euro. J. Clin. Microbiol. 32:1401-1408.

Rey J., Blanco J.E., Blanco M., Mora A., Dahbi G., Alonso J.M., Hermoso M., Hermoso J., Alonso M.P., Usera M.A., González E.A., Bernárdez M.I. \& Blanco J. 2003. Serotypes, phage types and virulence genes of Shiga-producing Escherichia coli isolated from sheep in Spain. Vet. Microbiol. 94:47-56.

Saei D.H., Ahmadi E., Kazemnia A. \& Ahmadinia M. 2012. Molecular identification and antibiotic susceptibility patterns of Escherichia coli isolates from sheep faeces samples. Comp. Clin. Pathol. 21:467-473.

Scheutz F., Nielsen E.M., Boisen N., Morabito S., Tozzoli R., Nataro J.P. \& Caprioli A. 2011. Characteristics of the enteroaggregative Shigatoxin/ verotoxin-producing Escherichia coli 0104:H4 causing the outbreak of haemolytic uraemic syndrome in Germany, May to June 2011. Eurosurveillance 16:1-6.

Stearns-Kurosawa D.J., Collins V., Freeman S., Tesh V.L. \& Kurosawa S. 2010. Distinct physiologic and inflammatory responses elicited in baboons after challenge with Shiga toxin type 1 or 2 from enterohemorrhagic Escherichia coli. Infecy. Immun. 78:2497-504.

Tesh V.L., Burris J.A., Owens J.W., Gordon V.M., Wadolkowski E.A., Brien A.D. \& Samuel J.E. 1993. Comparison of the relative toxicities of Shiga-like toxins type I and type II for mice. Infect. Immun. 61:3392-3402.

Wang G., Clark C.G. \& Rodgers F.G. 2002. Detection in Escherichia coli of the genes encoding the major virulence factors, the genes defining the 0157:H7 serotype, and components of the type 2 Shiga toxin family by multiplex PCR. J. Clin. Microbiol. 40:3613-3619.

Yamamoto S., Terai A., Yuri K., Kurazono H., Takeda Y. \& Yoshida O. 1995. Detection of urovirulence factors in Escherichia coli by multiplex polymerase chain reaction. FEMS Immun. Med. Microbiol. 12:85-90.

Zhang X.Y., Ding L.J. \& Fan M.Z. 2009. Resistance patterns and detection of aac(3)-IV gene in apramycin-resistant Escherichia coli isolated from farm animals and farm workers in northeastern of China. Res. Vet. Sci. 87:449-454.

Zweifel C., Schumacher S., Blanco M., Blanco J.E., Tasara T., Blanco J. \& Stephan R. 2005. Phenotypic and genotypic characteristics of non-0157 Shiga toxin-producing Escherichia coli (STEC) from Swiss cattle. Vet. Microbiol. 105:37-45. 